\title{
THE FALLACIES OF HARUN NASUTION'S THOUGHT OF THEOLOGY
}

\author{
Eka Putra Wirman \\ IAIN Imam Bonjol, Padang - Indonesia
}

\begin{abstract}
As one of the central figures in Islamic studies in Indonesia, Harun Nasution has made a great impact of influence. His model of theology has become a trend-setter and a blue-print in Islamic studies in this country for decades since the 1970's. As a loyal admirer and follower of the Mu'tazilah, Harun Nasution gave rise to the idea that Muhammad Abduh was a prominent Islamic reformer who agrees with Mu'tazilah doctrine and is even more liberal than the Mu'tazilah. To support his idea, Harun Nasution put forward Häshiyah 'alà al-Sharh al-'Aqầ'id Dawwani li alAdhudhiyyah by Muhammad Abduh which is the main reference for his famous book Muhammad Abduh dan Teologi Rasional Mu'tazilah. Harun Nasution's thought needs to be analyzed and reviewed methodologically, in order to make the theological thought always passionate and spared the stagnation and status quo. This study uses the main work of Harun Nasution Mubammad Abduh dan Teologi Rasional Mu'tazilah as its main source in addition to the book $A l$ Syaykh Muhammad 'Abdub bayna Al-Kalamiyyin wa AlFalasifah by Sulayman Dunya. Nasution's concepts are analyzed through content analysis which consists of data collection, classification, reduction, analysis, and conclusion.
\end{abstract}

Keywords: Theology, Harun Nasution, Muhammad Abduh, Mu'tazilah.

\section{Introduction}

In some segments of intellectual history of Indonesian Islam, Harun Nasution is without doubt one of the significant figures. Since the 1970's he has been a major influence in the Indonesian Islamic thought especially among academics of Islamic institues. One may say, 
almost every intellectual, thinker, and leading figure in Indonesian Islamic institutes today are among his students.

Owing to his role as a central figure, Nasution succeeded in making a typical model of curriculum for Islamic institutes in Indonesia which then serves as a blue-print for Islamic studies since at least the past three or four decades. One branch of study which totally follows his model is theology ( $\mathrm{ilm}$ al-kalam) in which it is almost a common rule in every stratum of education in Indonesia.

Despite his success and established ideas, some academically wellresearched studies have found out the fallacy of his theological thought. Some of the main reasons are; first, the inaccuracy of data which leads to a fallacious conclusion, second, the inconsistency of ideas which does not make solid grounds for an argument, and third, the ideological rather than academic nature of his concept which lacks objectivity.

This study then becomes relevant as to bring light on to the weaknesses and fallibilities of the long-established and dominating ideas of Harun Nasution in Indonesia's Islamic studies. Hopefully it can bring in some fresh air to the stagnant atmosphere of Islamic studies and give a new alternative to the old structure of theological thought, as it may also restore the spirit of true learning and study which is free of any ideological interest, so that it can be scientific, open and objective, methodological, accurate, and factual.

\section{The Weaknesses and Fallacies of Harun Nasution's Thought of Theology}

\section{Data Accuracy}

As a fully-fledged and academic model, Harun Nasution must be an expert who understands well how and which data to use to convey his ideas. As a matter of fact, he indeed used many references from various kinds of resources of which some are even not commonly referred to in Islamic studies in Indonesia. Most of his references are in languages other than Indonesian except for a few of them which must show his capacity and capability as a distinguished scholar.

Such various and numerous kinds of data sources naturally should go together with the accuracy and the right use of data. It is inevitably prerequisite in scientific research to have accurate and reliable data for only with them a reliable conclusion is possible. Less-reliable data are basically allowed only to support the existing valid data which means 
they can only serve as additional data in the main structure of a study or research.

In relation to this, Harun Nasution neglected the importance of data accuracy in order to pursue his ideological Mu'tazilan model. All the data he used as reference in his book Muhammad Abduh dan Teologi Rasional Mu'tazilab especially those related to the function of logic, the role of divine revelation, and the essence and nature of God do not match the data written in Hashiyah book which he had claimed as the main source of his inspiration.

Such data and information mis-match can be seen in several subjects he took from the book Häashiyah as follows:

\section{The function of logic and the role of divine revelation}

In accordance with Mu'tazilah, Harun said that human logic has an amazing extraordinary ability to probe into abstract things even without divine revelation. Among them are (1) The ability of logic to know God; (2) The ability of logic to know the obligation of gratitude toward God; (3) The ability of logic to know good and evil; and (4) The ability of logic to know the imperative of doing good and shunning evil. ${ }^{1}$

According to him, the high credit given to logic by Mu'tazilah is even still less compared to what Muhammad Abduh said about it. To Abduh, so Harun said, the ability and capacity of logic is so amazingly extraordinary that it can decide more than 4 points mentioned above especially on God and religious values even without divine guidance.

Still further on, he said that Mu'tazilah and Muhammad Abduh believe that men have no reason not to know and to implement those four points. If logic is not used to know them and their natural consequences, men will be punished for having violated the rules of logic itself. Such opinion by Mu'tazilah, as also ascribed to Muhammad Abduh by Harun, has been refuted by Abduh himself in his book Hasshiyah. The following are what he said about the four matters:

First, on the obligation of logic to know the existence of God. It is said in Häshiyab:

\footnotetext{
1 For more information on the ability of logic according to Mu'tazilah, see Harun Nasution, Muhammad Abdub dan Teologi Rasional Mu'tazilah (Jakarta: UI-Press, 1987), pp. 54-56. See also in Sulayman Dunya, al-Syaikh Mubammad Abdub bain al-Falasifah wa alKalamiyin (Cairo: Dar Ihya' al-Kutub al-Arabiah, n.d.), p. 200.
} 


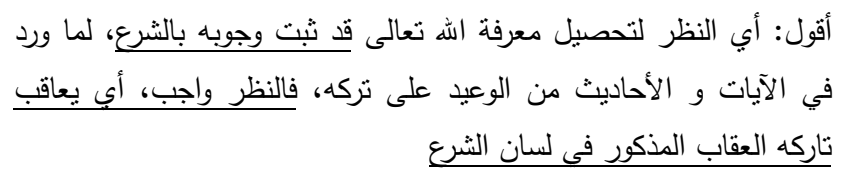

"I say that the effort to know God has been obliged by Islamic law (revelation) as it has been described in many verses in Qur'an as well as prophettraditions with some warning not to ignore it. This effot is obligatory that ignoring would mean grave consequence and punishment according to the set rules in Islamic law". ${ }^{2}$

Based on this paragraph, Abduh stated that the obligation to know and observe the existence of God (ma'rifat Alläh) is based on divine command or order. If there is no divine command there is no obligation on the part of men to do so which means there will be no sin or punishment in not doing it. Contrary to Abduh, the theology of Mu'tazilah says that logic obliges men to observe and know the existence of God despite no explicit command from God on it.

Second, the obligation to offer gratitude to God even not required by His order. Such obligation is also denied by Abduh in his book Häshiyah as he said nothing is required from men when God does not ask for it Himself through His revelation.

To make his argument clear, Abduh gave aquite elaborate example. When a poor man, out of ordinary, found golden money on his way there is no obligation on his part to find out the righteous generous person (al-muhsin) who has put the golden money. If he does not interact well or shows no respect or gratitude to the righteous person he cannot be blamed for his ignorance of who he is. And when the righteous person takes the money back from the poor man because of his ignorance and ingratitude, then the righteous person is none other than a fool. To Abduh, a righteous person (al-mubsin) basically never expects reward of any kind from the poor he has helped. If he wants some form of gratitude he should have shown himself to him. If he doesn't show who he is while at the same time expects some respect and some sign of gratitude, he actually has despised himself (سفه نفسه) for having committed such foolishness.

Abduh added,

2 Ibid., p. 197 


$$
\text { وإيذان بأنه علم صلب منه ذلانعه وخالقه وأنه الرازق لم يجب عليه شكره إلا بإيجاب منه }
$$

"Even if he (man) knows his creator who has bestowed him his livelihood and fortune, there is still no obligation on him to offer some gratitude unless He said He wants him to do so". 3

Abduh's words on this matter are firm and definitive that even if man knows that God has created him and has provided him his livelihood, logic still has no authority to oblige man to thank Him. Man is expected to do so only after God's saying so in the manner that He wants. If logic obliges man to thank God there's every possibility he may do it not as required. Analogically Abduh described those who offer gratitude without divine guidance as people likely to fall into the worship of idols or other beings, which in turn changes something meant as a devotion into a kind of polytheism and infidelity. ${ }^{4}$

Third and fourth, according to Mu'tazilah, logic is able to distinguish good from evil without divine guidance and also able to act accordingly to the knowledge of this good and evil. This stance is derived from their belief that good and evil are in-born qualities in each human being which means an act is called good because the quality of goodness is inherently built in the act itself as it is also the case with evil. Divine revelation then functions only to confirm what logic has decided.

Again, Abduh argued for this matter and clarified it in his book Hasyiah saying:

$$
\begin{aligned}
& \text { قولكم: (من سخط وجود شيء فقد سخط فاعله) مبني على أن من الأفعال } \\
& \text { ما هو حسن أو قبيح لذاته أو لصفة فيه. وليس كذللك؛ بل لا حسن ولا قبيح }
\end{aligned}
$$

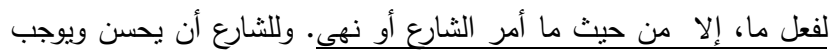

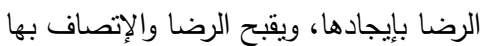

"Your saying, 'he who hates an act (something) certainly hates the doer of the act' is only reasonable on the grounds where it is believed good and evil are inherent qualities of every act. It is not so, an act is called good or evil not

\footnotetext{
3 Ibid., p. 202

${ }^{4}$ Ibid.
} 
because of the good or evil qualities in the act, but because God commands or forbids it. It is the right of God to call an act good and praises it or bad and condemns the doer". 5

On this point, Abduh explained that good and evil qualities are not inherent in any act, whatsoever. No act has good or evil qualities in it self as there is none can be associated and attributed to it. Attribution is solely the right of God to make through His revelation that without it no category can be made (theologically) on the grounds of theology. Consequently, logic has no authority attributing any act as right or wrong, good or evil, as it has no right to set rules on the command of righteous deeds and the prohibition of evil. All are within the rights of God, not logic.

To sum up all in simple words, Abduh said there is no obligation concerning religious matters leading to the consequence of reward or punishment can be attributed to logic. Matters like knowing God, offering gratitude or prayers, distinguishing evil from good and all its derivatives are not within the capacity of logic to have a say. Matters on theology, reward and sin, command and prohibition, are the domain of God wherein logic only functions to understand and explain. Therefore, none of the four points mentioned above is for logic to make a command through which either God's pleasure or His wrath may result.

Logic is to be used on matters like cultivating earth for people and prosperity. It is even required by Islamic law to make use of logic for worldly gains and benefits wherein the doer will get praises and merits for his efforts. Obligation on worldly affairs is not related with religious obligation especially on matters of sin and reward. A reward for those who bring worldly benefits is gaining praises from the benefited people, while a sin is the condemnation they get in failing to do what they are capable of. ${ }^{6}$

\section{Obligation to take care of Human Welfare (رعاية مصالح العباد)}

In the theology of Mu'tazilah which gives supreme credit to logic, God has many obligations toward His creatures. One of the obligations required of Him is to take care of human welfare (رعاية

\footnotetext{
5 Ibid., p. 491.

${ }^{6}$ Ibid., p. 200.
} 
so as to conform with His attribute Hikmah (Wisdom). Nasution said that Muhammad Abduh is also of the same opinion with this since it matches the principle of his theology which is far more developed and more rational than Mu'tazilah. ${ }^{7}$

Such opinion by Mu'tazilah is directly countered by Abduh saying that it is out of the position of man to put responsibility on God for $\mathrm{He}$ is the Supreme King who has absolute rules over the whole universe which consequently makes it insensible to put Him under any obligation or valuation over His actions. As a matter of fact, from time immemorial up to the appointed time later God has only been doing things which are full of Hikmah for the well-being of the universe without anyone expected Him to do so.

In the context wherein obligation has consequences of reward or condemnation, Abduh said that it is impossible for God for He is the source and the cause of everything. But to say He may or may not act according to what He has revealed is acceptable. To Abduh, there is no need to define the conformity of God's revelation and His action as an obligation on His part for He is free to act according to His will and wisdom. ${ }^{8}$

Abduh said that God cannot be put under obligation to take care of human welfare (masalitị al-'ibäd) as it is believed by Mu'tazilah. He further explained:

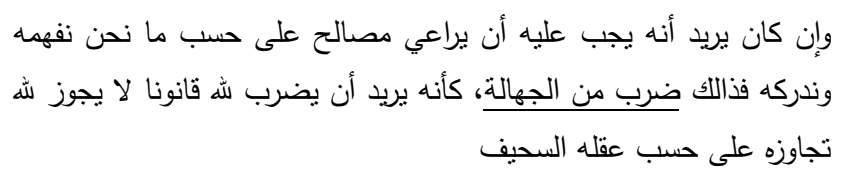

"And if they say that God has an obligation to take care of human welfare as we commonly understood it, then it is $\underline{a}$ sort of ignorance. It is as if they try to make rules for God to obey according to their simple ignorant minds".?

\footnotetext{
7 Mu'tazilah of Baghdad says that it is God's obligation to take care of men in their worldly affairs as well as in religion, while Mu'tazilah of Basrah says it's only in religious matters. According to the school of Baghdad, welfare or well-being is in terms of hikmah and control (al-hikmah wa al-tadbir) while to the school of Basrah it is in terms of benefit (al-naf'u)

8 Dunya, al-Syaikh Muhammad Abduh, pp. 546-547.

${ }^{9}$ Ibid., p. 549
} 
On this matter, Sulayman Dunya also confirms what Abduh has said as the following:

$$
\begin{aligned}
& \text { يقول: وما هو الأصلح للعبد، فليس بواجب على الله تعالى، وإلا لما خلق } \\
& \text { الكافر الفقبر المعذب في الدنيا والآخرة }
\end{aligned}
$$

"(Abduh said) : what may seems for the benefits of mankind is not on God to fulfill. Otherwise, there wouldn't be any miserable infidel who suffers in the world and the hereafter". 10

\section{On Dhat and Șifat of God (The Essense and Attributes of God)}

Inaccuracy of data and description is also found out in Nasution's reference to Muhammad Abduh's thought concerning Dhat and sifat of God (the Essence and Attributes of God). Said Nasution, Abduh didn't clearly explain the nature of Dhat and sifat; of whether they are identical or different, whether sifat is other than Dhat or not other than Dhat. To his opinion, Abduh didn't do so because he believes that if God has any attribute it must certainly be qadim (eternal) which consequently makes a long list of qadim attributes along with the essence of God which is qadim. The belief in the existence of qadim attributes for God other than His qadim Dhat (Essence) would do harms to the idea of Tawhid (ta'addud al-qudamáa). ${ }^{11}$ This idea, wrongly ascribed to Abduh, is basically the core belief in the theology of Mu'tazilah which is denial of any attribute to God, a belief which then gives its followers the call 'al-mu'athilab' ( disbelievers in the attributes of God ).

Nasution's claim supposing Abduh as to disbelieve in the attributes of God goes against Abduh's statement itself in the book Hasshiyah. Abduh explained the existence of Dhat and Sifat of God referring to Imam al-Ash'ari as follows:

$$
\text { أن الصفات لا يقال فيها هي هو ولا غيره ولا لا هو ولا لا غيره }
$$

\footnotetext{
${ }^{10}$ See the comments of Dunya, al-Syaikh Mubammad Abduh, p. 35

${ }^{11}$ Nasution, Mubammad Abduh dan Teologi Rasional, p. 74
} 
"The sifat (attributes) of God cannot be said as Dhat (Essence) nor as Other than Dhat, nor can it be said as NotDhat nor as Not-other than Dhat."12

According to Abduh, when sifat is said to be different from Dhat ( الغير = Not-it) logically it will be construed as the opposite of the word (Not-it = اللا غير). But al-Ash'ari negates both while consistently stands for the essential and existential substance of those sifat (atributes). Naturally it is quite complicated for logic to comprehend, but according to Abduh, Ash'ari has broader vision than what could be said through words.

To Abduh, sifat is essentially a logical, philosophical, and abstract quality which cannot be personified in material entity (al-wnjüd alkhawariji). Something which is existentially immaterial (ghayru manjü $\bar{f}$ al-khariji) should be freed from all associations of material entity (alkhärij). And it is this material dis-association which is termed as 'sifat is not Dhat (لاهو). Then as not to deny the existence of sifat and Dhat, it should be said simulteneously that 'sifat is also Not-other-than Dhat (لالاهو) which is the opposite term for Not-Dhat (لاهو).

Further on Abduh reiterated the obligation of faith in the existence of sifat which is not Dhat nor as something other than Dhat. The sifat of God is not within the boundaries of material definitions (al-khariji) which consequently makes it imperative to dis-associate it from all of them through a way of negation (al-nafyu). And sifat should also be different from the negated which then makes it negating-negation (nafyu al-nafyi). ${ }^{13}$ Through these two methods Ash'ari and Abduh sum up their point that the belief in sifat or attributes of God is obligatory. In Häshiyah Abduh said:

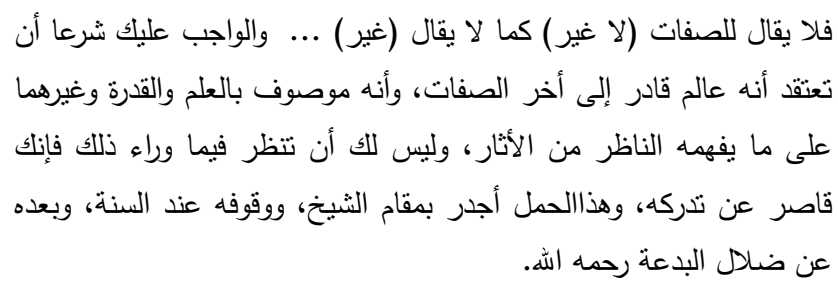

12 Dunya, al-Syaikh Mubammad Abduh, p. 330

13 Ibid., p. 331 
"It may not be said that sifat is not Not-Dhat nor may it be said as Other than Dhat ..... what must be held in religious teaching is that God is All-knowing ("Alim), All-mighty (Qadir), and He also has the sifat of of al-'ilm, al-qudrah, and other sifat as the intellectual ulamas have understood it from the prophet traditions. An inquiry into the secret mystery of this matter is not allowed for you will not be able to comprehend it. This insight serves very well as to shed the light on the understanding of al-syeikh (al-Ash'ari) who steadfastly adheres to the prophet traditions and shuns from all sorts of heretical ignorance, God blessed him."14

In reference to this argument, Abduh believes that sifat is something existentially and essentially existent and unique. It cannot be non-existent as it is also impossible for it to take a form which negates other sorts of existence.

Such philosophical brilliant insight and analysis by both al-Ash'ari and Abduh may not be shared by other than certain capable people (alkhawnass). It may not even be found in the writings and explanation of Ash'arian ulemas of the past. Specifically Abduh even critisized those who follow Imam al-Ash'ari but do not understand rightly what he said about the sifat of God. Most of them believe that sifat has its own

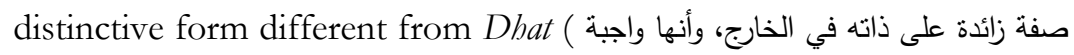
(الوجود لذاتها

Firmly and critically he said that anyone who claims the above idea (that sifat is someting more than Dhat distinctively separate as 'wajib alwujud') does not deserve the call as a follower of Imam al-Ash'ari, a member of Ash'ariah, or a follower of Ahlussunnah. In fact, he belongs to those groups of ignorant people who speak what they don't know about God in spite of their interestingly coloured ideas and words. ${ }^{15}$

Abduh realized that the idea 'sifat is something more than Dhat distinctively separate as wajib al-wujud' has long been prevalent in some groups of Ash'ariah. A misleading idea very much contradictory to the concept of Tawhid for it may lead to a notion that the sifat of God has its own entity other than God. It has indeed caused a bad image on Imam al-Ash'ari wherein Abduh thinks it necessary to make a clear and

\footnotetext{
${ }^{14}$ Ibid., p. 332

15 Ibid., p. 333
} 
comprehensive explanation to support and restore the honor of this highly-respected model ulema in theology.

He wrote in Hashiyah referring to the statement of Imam al-Ash'ari on the existence and the essence of sifat of God as follows:

$$
\begin{aligned}
& \text { وأنا أقول: قد وققت عند النظر في قول الثيخ المنقول من كتابه على ما }
\end{aligned}
$$

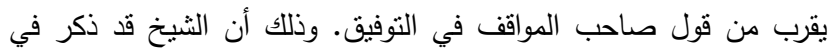

$$
\begin{aligned}
& \text { مقالته [أن الصفات لا يقال فيها: هي هو ولا غيره ولا لا هو ولا لا غيره] }
\end{aligned}
$$

"I (Abduh) say, (related to this matter on sifat and Dhat) I have thoroughly analyzed and seen what al-syeikh (alAsh'ari) said in his book, which comes close to what the writer of Al-Mawaaqif (al-Idji) said, that he (al-syeikh) has said in his book the sifat of God may not be said as equal to Dhat nor as Other than Dhat, nor may it be said as Not-Dhat nor as Not-other than Dhat." 16

What Abduh said in the paragraph defining șifat not equal to Dhat nor Other than Dhat, nor may it be said as Not-Dhat nor as Not-other than Dhat' is clearly an authoritative word by Imam al-Ash'ari which is needless to doubt. Further on Abduh added:

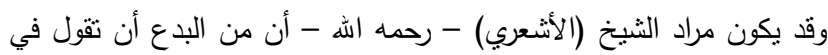

$$
\begin{aligned}
& \text { صفات اللة: أنها عينه، أو إنها غيره، أو إنها لا عينه، أو إنها لا غيره }
\end{aligned}
$$

"What he al-shaykh (al-Ash'ari) -God blessed him- means is that it is a sort of heresy to say that sifat of God is identical with His Dhat ('aynubu) or as Other than His Dhat or as Not-His Dhat (la' 'aynubu) or as Not-other than His Dhat (ghayrubu)." ${ }^{17}$

Evidently it brings to the fact that Abduh never doubted the ascription of the statement to Ash'ari as Nasution claimed in the following:

"He (Abduh) doubted that the concept originated from Ash'ari himself, because one statement of the founder of

\footnotetext{
16 Ibid., p. 330

17 Ibid., p. 331
} 
this school of thought leads to the opposite idea (of negating sifat)."18

From this data, a contradiction is clearly seen between what Abduh wrote in Hashiyah and what Nasution said in Abduh's name with the same reference. Such striking discrepancy happened becaused Nasution used inaccurate data which directly go against the facts. Similar to what happened earlier, this case shows that Nasution has never really referred to the book Hasshiyah in many core subjects of theology.

His inaccuracy of data becomes more evident when Nasution tried to explain away what Abduh said about the following:

$$
\text { ليس في الدار غير زيد، أو ليس فيها عشرة رجال }
$$

"There is no one in the house except Zayd, or there are not ten men inside it". ${ }^{19}$

He commented it as follows:

"According to the school of Ash'ari, if the expression 'there is no one in the house except Zayd'(ليس في الدار غير 'Aيد) excludes the attributes and other parts (sic) of Zayd as different from him, then those attributes and parts are among things absent in the house, while in fact they are there for Zayd cannot be without those attributes and parts. To Abduh, this argument is weak, because what is meant in the expression 'there is no one in the house except Zayd' is everyone except Zayd and not the attribute and part of Zayd". ${ }^{20}$

To Nasution, the sentence (لبس في الدار غير زيد) means that in the house there is everyone but Zayd and neither his attributes nor parts of his body nor his belongings are there. It became so because he didn't correctly quote the data from the book Hasshiyah. Either intentionally or not, he has taken away one very important word written in the book Hâshiyah namely لنفي (to negate/to deny). The following is the original paragraph by Abduh which is wrongly quoted by Nasution:

\footnotetext{
18 Nasution, Mubammad Abduh dan Teologi Rasional.

${ }^{19}$ Dunya, al-Syaikh Mubammad Abduh, p. 306

${ }^{20}$ Ibid., p.73
} 


$$
\begin{aligned}
& \text { فقولك (ليس في الدار غير زيد) مسوق لنفي كل رجال سواه ، أو إنسان } \\
& \text { سواه،أو عالم سواه أو ما يثبه ذلك. }
\end{aligned}
$$

"Your saying (there is no one in the house except Zayd) is meant to negate everyone else except Zayd, or any human other than Zayd, or any sign other than Zayd, or any other similar examples." 21

Looking into the underlined words written in Hasshiyah and those by Nasution one will immediately see the obvious difference. Nasution said the meaning of the expression (لبس ف الدار غير زيد) is everyone

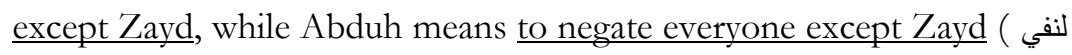
not to negate Zayd himself as written by Nasution.

Because of this distortion of the word li nafyi, a completely different idea came in and changed the meaning intended by the original author. It created a false assumption as if Abduh agrees with Mu'tazilan idea of the identicality between sifat and Dhat of God while in fact he has always been firm and consistent to say that sifat as well as Dhat are essentially existent in accordance with Imam al-Ash'ari's standpoint.

Abduh used this term in order to clarify the definition of sifat as mentioned above. In semantics terminology, 'there is no one in the house except Zayd' means that either Zayd or his attributes are in the house. He may not be physically in the house but his attributes like clothes, vehicle, and possessions are there which may serve enough grounds to say that 'in the house there is Zayd'. Linguistically (esp. Arabic), the existence of Zayd in the house cannot be denied because of all those attributes that represent him. On the other hand, they cannot literally stand for physical existence of Zayd either (la buwa), as they may not be said to have no connection with him (la ghayrubu).

In addition Abduh said that in Arab or even Islamic tradition, the expression (ليس في الدار غير زيد) means to say that there is not anybody in the house other than Zayd himself (and his attributes) which means he who touches Zayd's shirt has symbolically touches Zayd and he who

${ }^{21}$ Ibid., p. 307 
hits Zayd's hand has actually has hit him ( من أمسك بثوب زيد، أمسك زيدا، من 20. (ضرب يد زيد، ضرب زيدا

Such terms and expressions, said Abduh, are commonly found and used in Arabic language and legal figh. That is why he and al-Dawwani used this example to set the difference between là 'ainiyah (لاهو / لاعينه) and la ghayriyah (ولاغير) in the subject concerning the sifat of God. He believed that this method can only be understood by linguists and philosophers (أهل اللغة والعرفاء). Common lay people unaccustomed to liguistics and philosophy may not be able to understand it or even worse, mis-interprete it.

\section{Consistency}

Aside from the inaccurate and misleading data, Nasution is also not consistent in and with his ideas. This inconsistency can be clearly seen in some important matters such as the role and position of Risalah Taubid in theological study as compared to the book Hashiyah.

Riasalah Taubid (A Treatise on Tawhid) is a magnum-opus by Muhammad Abduh highly-regarded as reference in theology up to the present day. Majid Fakhri valued the book as a monumental work by Abduh, well-systematized, and put its quality as equal to the great works of Mu'tazilan figures in the late VIII century such as Sharh Usül al-Khamsah by Qadhi Abdul Jabbar. ${ }^{23}$

Realizing the values of its materials, systematization, and use, some writers have translated it into several foreign languages such Urdu, French, and others. B. Michelle, for example, in collaboration with Musthafa Abdurraziq translated the book into French in 1925, while Ishaq Musa'ad together with Kenneth Cragg made it into English. ${ }^{24}$ Risalah Taubid has also been used as reference book in several world leading universities such Alligarh university in India and Istanbul University faculty of literature, Turkey. ${ }^{25}$ In spite of such high appreciation and expectation from both West and Islamic worlds

\footnotetext{
22 Ibid., p. 308

23 Majid Fakhri, A History of Islamic Philosophy, translated by Mulyadhi Kertanegara (Jakarta: Pustaka Jaya, 1987), p. 464.

${ }^{24}$ Nasution, Mubammad Abduh dan Teologi Rasional, p. 2

${ }^{25}$ Muhammad Abduh, Risalat al-Taubid (Beirut: Dar Ihya' al-'Ulum, 1986).
} 
Nasution tried to de-valuate it and changed its image by calling it as a book suitable 'only' for high-school level kind of reading. ${ }^{26}$

A surprisingly odd statement indeed, in comparison to what the East and the West have to say about the high value of this magnum opus by Abduh as a reference book in theology. All reasons aside, maybe such negative response of his has its sense in his tendentious ambition to settle down the theology of Mu'tazilah and to negate the others. Obviously, Risalab Taubid is not the kind of book which leaves some space for him to pursue his project since it contains teachings on the sifat of God which is one of the basic subjects denied by Mu'tazilah. ${ }^{27}$

After degrading Risalah Taubid, did Nasution then make Hashiyah his reference in matters pertaining philosophy and theology? According to a research, Nasution is also not consistent with his own ideas and claims concerning these two works of Abduh. Contrary to his own claim, in the book 'Muhammad Abduh dan Teologi Rasional Mu'tazilab' wherein he strongly associated Abduh and his ideas as Mu'tazilan, he surprisingly made Risalah Taubid as his main important reference. Hashiyah only comes second, and that's too not on matters related to philosophy or theology.

A simple calculation has found out that there are 266 foot-notes made in the book 'Muhammad Abduh and the Rational Theology of Mu'tarilab'. 144 of them refer to Risalab Taubid, 94 to general books which amount to 23 books, and only 28 refer to Hashiyah. It means that in order to show Abduh's type of theology which he claimed more rational and more advanced than Mu'tazilah he made 50\% reference to Risalab Taubid and only less than $10 \%$ to Hashiyah, which again only on non-philosophical matters of theology.

To Hashiyah Nasution referred 17 times on the sifat of God, 5 times on the acts of God, 5 in the conclusion, and 1 in the introduction. But it is never referred to concerning important core subjects in philosophy and theology such as the philosophy of existence, the power of logic, the function of divine revelation, the concept of faith, free will, and determination.

\footnotetext{
${ }^{26}$ Nasution, Mubammad Abdub dan Teologi Rasional, p. 5 and p. 74.

${ }^{27}$ Some Western writers like Charles C. Adam, M. Horten, Michael B and MacDonald concluded that Muhammad Abduh's type of theology is Ahlussunnah and Asy'ariah.
} 
This makes it clear that Nasution contradicted his own ideas by making Risalah Taubid as his main reference on important philosophical-theological subjects instead of Hashiyah. So, using his own words one may say that the academic work of Nasution Nasution titled Mubammad Abdub danTeologi Rasional Mu'tazilah which is excerpted from his doctorate dissertation is more suitable for high-school than university students because its materials come from the supposedly low Risalab Taubid, not from the highly-philosophical Hashiyah.

The table below shows how inconsistent he is regarding his claims on 'shallow' Risalab Taubid and fine Hashiyah in which he refers mostly to the former and rarely to the latter.

Table 1: Subjects and Chapters discussed in the book of Muhammad Abduh dan Teologi Rasional Mu'tazilah by Harun Nasution

\begin{tabular}{lll}
\hline & Hashiyah & Risalah \\
\hline Introduction & $1 / 22$ & $3 / 22$ \\
Background of the writer & $0 / 34$ & $0 / 34$ \\
Philosophy of existence & $0 / 51$ & $51 / 51$ \\
Logic & $0 / 47$ & $43 / 47$ \\
Revelation & $0 / 21$ & $19 / 21$ \\
Free Will & $0 / 25$ & $16 / 25$ \\
Nature & $17 / 61$ & $9 / 61$ \\
Acts of God & $5 / 19$ & $2 / 19$ \\
Faith & $0 / 13$ & $3 / 13$ \\
Conclusion & $5 / 7$ & $1 / 7$ \\
\hline Total & $28 / 266$ & $144 / 266$ \\
\hline
\end{tabular}

Such discrepancy between what he claimed and what he did shows how inconsistent Harun Nasution is in academic scientific study. An attitude which brought harms to the scientific objective tradition of academic world leading to fallacious ideas in the mind of academic communities and common people.

\section{Ideological Nature and Orientation}

In the book '70 tahun Harun Nasution (70 years Harun Nasution)' written by several national writers, Nasution openly said his admiration on the theology of Mu'tazilah. ${ }^{28}$ Not only through words he even once

28 Panitia Penerbitan Buku dan Seminar 70 Tahun Harun Nasution, Refleksi Pembaharuan Pemikiran Islam: 70 tabun Harun Nasution (Jakarta: Panitia Penerbitan Buku dan Seminar 70 Tahun Harun Nasution - Lembaga Studi Agama dan Filsafat, 1989). 
attached the name of Abdul Jabbar ${ }^{29}$ to his name which shows certain obsession on his part to show the superiority of this theology along with some serious tireless efforts to make it as the one dominant model of theology in Indonesia. Such a common and understandable dream.

His struggle and efforts, as already known, bear fruits of success especially among academics of Islamic institutes in Indonesia. Among the key reasons to this success are his strategic structural position, the numerous variety of his data sources which are relatively new to his listeners, and his fair skill in rhetoric which enables him to counter all sorts of criticisms addressed toward him.

The following are some examples of his efforts to establish the theology of Mu'tazilah as the one model of theological study: First, Defining theology the Mu'tazilan way and debasing as well as negating other models of theology systematically, he put himself not as an academic of theology but as an ideologist of Mu'tazilah. In his opinion, there are only two kinds of theology, rational and irrational. Such categorical division certainly brings about disfavours not only to the branch of theology (ilmu al-kalam) but also to academic tradition as it leads to an idea that theology and theologians are but stages for Mu'tazilah's show in which others like Ahlussunnah (Ash'ariah and Maturidiah ) are only minors to cheer the great performance.

Like a story of heroes which needs some villains to blame, the theology of Ahlussunnah becomes the lowly culprit responsible for the irrational attitude of moslems which causes stagnancy and setback. It is even referred to as synonyms for fatalism, jabariah, pessimism, laziness, and life without future. The theologians of Ahlussunnah are also perceived as blind people ignorant of Qur'anic verses on encouragements to think and contemplate, to struggle and cultivate, to lead and co-operate as they are often described unnecessarily too much preoccupied with verses on the mightiness and grandeur of God. Nasution seems to forget that many good reference-books on ijtihad, fiqh, maqashid, ushul-figh, kalam, and Islamic sociology are the academic works of Ahlussunnah big family. He also seems to neglect the fact that Mu'tazilah has lost its ground and place since the late era of khalifa Ma'mun and Mu'tashim up to the present day. This loss is not

\footnotetext{
${ }^{29}$ Abdul Jabbar is Qadhi al-Qudha Abdul Jabbar al-Hamdzani, a Mu'tazilian figure in the VIII century of Hijriyah. As he passed away, there's hardly any prominent figure of Mu'tazilah up to the present days.
} 
merely caused by their loss of power but mainly because of their theology which misfits the natural tendency of human beings for the presence of God in their life through prayers, rituals, hopes, and other kinds of observance. A religious belief that denies the active participation of God is better called philosophy on God than a religion which functions to fulfill human spiritual need. And his version of theology leads people to Deism ${ }^{30}$ which is considered primitive by Zakiah Drajat, an expert figure on the world's religions. ${ }^{31}$

Second, To support his argument for Mu'tazilah, Nasution used the named of Muhammad Abduh as the icon to personify the most rational of Mu'tazilah (the better version of Mu'tazilah or the more Mu'tazilah than Mu'tazilah itself). This conclusion is completely and elaborately discussed in his book 'Muhammad Abduh dan Teologi Rasional Mu'tazilab'.32 Through this book as well he made the work of Muhammad Abduh 'Häshiyah 'alà Sharh al-Dawwani lì al-'Aqidah alAdhudhiyyab' (further called Häshiyah) as the 'magic wand' to glorify the Mu'tazilan way of Muhammad Abduh and to degrade and discredit Ash'ariah. At least for the past 30 years he managed to make the charm work, but a new critical-analytical study proves that the book Hashiyah which he claimed as purely Mu'tazilan shows so factually and accurately that Muhammad Abduh is basically Ash'arian. ${ }^{33}$ With these academically proven facts, the spell that has long lullabied will soon be over and the dominating way or model of ANY theology will no longer have its say for it will no longer be taught in any educational institutions especially not in Islamic institutes.

Third, Nasution tried to discredit and relegate the philosophical value of Risalab Taubid (A Treatise on Tawhid), another work by Muhammad Abduh on theology. Such attempt on its devaluation is driven by his disappointment in the model of theology of this book which is so Ash'arian or Ahlussunnah especially on the subject

\footnotetext{
${ }^{30}$ Deism is a belief in God as the creator of the universe who then takes no more concern of it and leaves it moving on according to the sets of law He has created. To a deist, it is of no use hoping God to come back and take care of His creatures. Therefore, a deist does not believe in rituals, prayers, and seeking for God's help. See Harun Nasution, Falsafat Agama (Jakarta: Penerbit Bulan Bintang, 1975), p.35

${ }^{31}$ Some people consider Deism as a sort of belief of primitive people.

32 Nasution, Mubammad Abduh dan Teologi Rasional.

33 See Eka Putra Wirman, The Testimony of Hasyiah on the Theology of Mubammad Abduh (Research Center of IAIN Imam Bonjol, Padang, 2011), over several pages.
} 
pertaining the essence and the attributes of God. As he didn't find any sign or colour of Mu'tazilah in the book he labelled it as 'a low-level reference book'. He finds some justification by referring to Muhammad Abduh's preface in the book that the content of Risalah Taubid is inspired and taken from the study materials of Madrasah Thānawiyah Sultāniyah (a sort of Senior High School) in Beirut, 1887. Thus, according to him, it is unlikely to find some high-value philosophy in the book as it is difficult to classify its worth for it. Instead, he proposed Hashiyah, the book mentioned earlier, as a proof of Muhammad Abduh's favour for rationalism, liberalism, philosophism, and Mu'tazilism. But, another research has also found out that the book Mubammad Abduh dan Teologi Rasional Mu'tazilah for which he writes to prove and support the assumption of Muhammad Abduh as Mu'tazilan has never in fact referred to Häshiyah book on the philosophical-theological subject matters such as the philosophy of existence, the function of logic, the role of divine revelation, the philosophy of free-will, and the concept of faith. For these matters, surprisingly, he used Risalab Taubid, the book he has claimed not so rational and philosophical for its high-school level. It becomes all the more reason for him to lose his grounds since Häshiyah, the book upon which he put all his theories and arguments for Mu'tazilah is actually and factually a great work dedicated to the theology of Ahlussunnah and Ash'ariah.

All these facts show how ambitious he was to set the ideology of Mu'tazilah as a ruling model in Islamic studies in Indonesia. An ambition which sets aside all sense of academic and scientific objectivity, factual and accurate data, to pursue his ideological mission.

\section{Conclusion}

To sum up the brief study above, here are some main points:

1. This study finds out that almost all ideas of Harun Nasution written in the book Mubammad Abduh dan Teologi Rasional Mu'tazilah which he said refer to Häshiyah are direct opposites of the contents of Häshiyah. Such irresponsible act has tampered and damaged the the principle of data accuracy which is a basic main principle in every academic work.

2. He claimed Risalab Taubid as having no rational philosophical analysis in theology which makes it only suitable for students in senior high-schools, but in actual fact made it his primary source 
of data on theological philosophical matters. At the same time, he convincingly claimed Hashiyah as the valid main reference to prove the rationalism of Muhammad Abduh but made it only secondary or even only complementary data resource.

3. Due to these academic fallacies in its methodology and analysis, Harun Nasution's concept of theology proved to be fatally fallacious and needs reformulation. In-depth and impartial study is required in every sort of academic work so as to make it accurate and objective. The spirit of serving the truth should be revived and restored so that freedom, honesty, and scientific attitude become the underlying values that will prevent any kinds of prejudices from undermining the integrity of any man of learning. Quoting one of Minangkabau proverbs, an immediate serious measure to respond the problem should be immediately taken so that 'siriah pulang ka tampuaknyo pinang pulang ka gagangnyo'. (Let and put things where they belong)

4. In the context of theological study, Harun Nasution presented his academic work in a way disguising his ideological mission which then turned all his academic energy into some vested primordial interests. The ideology he strived to set is the ideology of Mu'tazilah.

5. As a result of ideological interest, his academic work and conclusion cannot be said scientifically and academically objective since it has violated the academic codes itself such accuracy of data and consistency of ideas.

To complete the findings above with necessary response, the following points are suggested as necessary follow-up:

1. Similar critical researches on other works of Harun Nasution are needed so as to make them rightly viewed and appropriately put in perspective.

2. Reviving the true spirit of learning which is free, critical, and academic is essential so as to restore the progressive culture of learning in general and to avoid vested-interests and stagnancy in particular.

3. Further study on the book Al-Shaykh Muḥammad 'Abdub bayna AlKalamiyyin wa Al-Faläsifah by Sulayman Dunya might also be necessary as to know its type of theology.

Hopefully this research can serve as a driving force to the creating of truth-based academic culture which leads to enthusiasm for human 
and scientific progress. The submissive and apathetic attitude prevalent nowadays would cause some stale atmosphere in the academic world which leads to the setback of academic culture in particular and Islamic civilization in general. An attitude contradictory to the spirit of Islamic scientology for a better life and more civilized society. Wa Allāhu a'lamu bi al-sawāb. []

\section{References}

\section{Books and Articles}

Abduh, Muhammad. Risalat al-Taubid. Beirut: Dar Ihya' al-'Ulum, 1986.

Al-Baghdadi, Abdul Qahir ibn Thahir ibn Muhammad. al-Farq bayn alFiraq. Beirut: Dar al-Kutub al-Ilmiah, n.d.

Amin, Ahmad. Zu'amā al-Islāh fí al-Ashr al-Hadith. Cairo: Maktabah alNahdhah al-Misriah, 1965.

Dunya, Sulayman. al-Syaykh Muhammad 'Abduh bayn al-Falasifah wa alKalamiyyin. Cairo: Dar Ihya' al-Kutub al-Arabiah, n.d.

Emarah, Muhammad. al-A'māl al-Kämilah li Jamāl Al-Dìn al-Afghāni. Beirut: n.p., 1979.

-------. Rasa'il al-'Adl wa al-Tawbìd. Beirut: Dar al-Syuruq, $2^{\text {nd }}$ edition, 1988.

Fakhri, Majid. A History of Islamic Philosophy, translated by R. Mulyadhi Kertanegara. Jakarta: Pustaka Jaya, 1987.

Gharbal, Syafiq. al-Mansu'ab al-'Arabiyah al-Muyassarah. Cairo: n.p., 1965.

http://www.cis-ca.org/voices/a/afghni.htm

Nasution, Harun. Falsafat Agama. Jakarta: Penerbit Bulan Bintang, 1975.

---------. Muhammad Abduh dan Teologi Rasional Mu'tazilah. UI-Press, 1987.

Panitia Penerbitan Buku dan Seminar 70 Tahun Harun Nasution. Refleksi Pembaharuan Pemikiran Islam: 70 tabun Harun Nasution. Jakarta: Panitia Penerbitan Buku dan Seminar 70 Tahun Harun Nasution - Lembaga Studi Agama dan Filsafat, 1989. 
Wirman, Eka Putra. Kesaksian Hasyiah terhadap Teologi Muhammad Abduh. Puslit IAIN Imam Bonjol, Padang, 2011.

Zainal, Muhammad, Teologi Mubammad Abdub: Studi terbadap Risalah Taubid dan Hasyiah 'ala Syarh al-Dawwani li al-'aqaid alAdhudhiyyah, unpublished MA Thesis, postgraduate program of IAIN Imam Bonjol Padang, 2007. 